\title{
Språkspalten
}

\section{Gode og dårlige nyord}

\author{
Tidsskriftet fører en restriktiv linje når det gjelder bruk av ord med \\ opphav i engelsk eller andre fremmedspråk. Men nye ord har ikke \\ nødvendigvis livets rett selv om de er genuint norske.
}

En av Tidsskriftets viktige oppgaver er å holde i hevd et norsk medisinsk fagspråk. Derfor er redaksjonen med rette restriktiv når det gjelder å akseptere anglisismer og annen fremmedspråklig påvirkning, og forfatterne oppfordres til å unngå fagsjargong og slang.

I mange tilfeller er det ønskelig å finne gode norske uttrykk når nye ord dukker opp i internasjonal faglitteratur. Et vellykket ekempel er «enkeltnukleotidpolymorfisme» for «single nucleotide polymorphism» (1). Men ikke alle nye ord er gode eller ønskverdige, og det at de er norske, er ikke i seg selv et tilstrekkelig kriterium for at de bør aksepteres. Skal Tidsskriftet fortsatt ha en rolle som røkter av det norske fagspråket, bør man se kritisk også på norske nyord.

Ordet «samhandling» har spredt seg med forbausende hastighet og i enkelte miljøer fått klart preg av slang. Overraskende nok har Tidsskriftets redaksjon tilsynelatende uten motstand sluppet det inn i spaltene, og i nr. 11/2009 var det å finne i minst to overskrifter $(2,3)$ og i enda flere av artiklene.

Hva er galt med det gamle ordet «samarbeid»? Det er fint at språket blir rikt og variert, men nye ord må i det minste tilføre en ny nyanse dersom de skal ha livets rett. I motsatt fall dreier det seg vanligvis om moteord, floskler og klisjeer. Prøv å skifte ut «samhandling» med «samarbeid» i referanse 2 og referanse 3 ! Blir nyanser, presisjonsnivå eller språklig rikdom forringet? Jeg synes ikke det. «Samhandling» er lansert i den politiskbyråkratiske sandkassen, først og fremst som betegnelse for det samarbeidet som foregår (eller burde ha foregått) mellom helsepersonell ansatt på ulike forvaltningsnivåer. Selvfølgelig er slikt samarbeid viktig. For viktig til at det bør få koke bort i nyspråklig svada. Tidsskriftet bør stå vakt om den språklige stringensen, også når truslene kommer annetsteds fra enn det angloamerikanske språkområdet.

\section{Torgeir Bruun Wyller}

t.b.wyller@medisin.uio.no

Geriatrisk avdeling

Oslo Universitetssykehus, Ullevål

\section{Litteratur}

1. Bjørheim J, Ødegaard R. Enkeltnukleotidpolymorfisme. Tidsskr Nor Lægeforen 2005; 125: 316 .

2. Grimstad O. Samhandling. Tidsskr Nor Legeforen 2009: 129: 1077

3. Førland O, Zakariassen E, Hunskår S. Samhandling mellom ambulansearbeider og legevaktlege. Tidsskr Nor Legeforen 2009; 129: 1109-11.

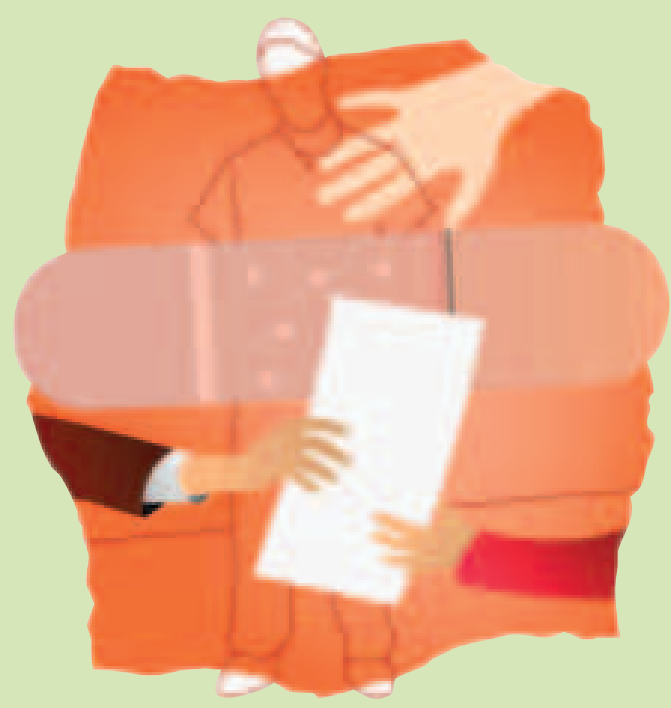

Illustrasjon Images.com/Corbis/SCANPIX 